\title{
Distribution and ecology of Haemaphysalis concinna (Parasitiformes, Ixodidae) in the Kuznetsk-Salair mountain area (Kemerovo region and adjacent regions, Russia)
}

A.V. Kovalevskiy ${ }^{1,2^{*}}$, S.S. Oplachko ${ }^{3}$, K.S. Zubko ${ }^{3}$, E.M. Luchnikova ${ }^{3}$, A.R. Efimova ${ }^{4,5}$, V.B. llyashenko ${ }^{1}$, A.V. Korshunov, E.D. Vdovina ${ }^{3}$, M.A. Noskov ${ }^{3}$, B.G. Andreyev 6

\author{
${ }^{1}$ Biological station "Azhendarovo", Kemerovo State University, Krasnaya Str. 6, Kemerovo \\ 650000 Russia. \\ ${ }^{2}$ Department of Landscape Architecture, Kuzbass State Agricultural Academy, Markovtseva Str. 5 , \\ Kemerovo 650056 Russia. \\ ${ }^{3}$ Department of Ecology and Nature Management, Kemerovo State University, Krasnaya Str. 6, \\ Kemerovo 650000 Russia. \\ ${ }^{4}$ Center of Hygiene and Epidemiology of Kemerovo Province, Shakhterov Ave. 20, Kemerovo, \\ 650002 Russia. \\ ${ }_{5}^{5}$ Department of Epidemiology, Kemerovo State Medical University, Voroshilov Str. 22A, Kemerovo \\ 650056 Russia \\ ${ }^{6}$ Department of Botany, Tomsk State University, Lenina Str. 36, Tomsk 634050 Russia. \\ *E-mail: passer125@yandex.ru
}

ABSTRACT: In the course of complex ecological and faunistic field studies in the Kemerovo region in 2019, the distribution pattern of Haemaphysalis concinna C.L. Koch,

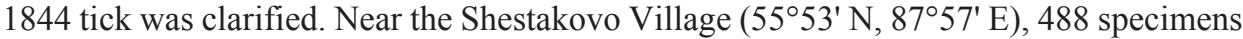
of this species were collected. This is the most northern habitat of this species from reliably known ones, located more than $170 \mathrm{~km}$ from the previously known northern boundary of the distribution. Even more northern finds of this species are sporadic and are probably related to the transfer of single specimens by birds. The new habitat discovery required a reassessment of all information regarding distribution and hosts of this species in the Kuznetsk-Salair mountain area. The article describes $H$. concinna distribution within the region. Since the vast majority of larvae and nymphs near the Shestakovo Village were found on bluethroats Luscinia svecica (Linnaeus, 1758), the possible mechanism of such H. concinna populations formation and the role of birds in tick distribution are considered in the work.

How to cite this article: Kovalevskiy A.V., Oplachko S.S., Zubko K.S., Luchnikova E.M., Efimova A.R., Ilyashenko V.B., Korshunov A.V., Vdovina E.D., Andreyev B.G., Noskov M.A. 2020. Distribution and ecology of Haemaphysalis concinna (Parasitiformes, Ixodidae) in the Kuznetsk-Salair mountain area (Kemerovo region and adjacent regions, Russia) // Invert. Zool. Vol.17. No.2. P.133-144. doi: 10.15298/invertzool.17.2.03

KEY WORDS: ixodid ticks, population, abundance, birds, migration, West Siberia, Altai. 


\section{Распространение и некоторые особенности экологии Haemaphysalis concinna (Parasitiformes, Ixodidae) в Кузнецко-Салаирской горной области (Кемеровская область и прилегающие регионы, Россия)}

\section{А.В. Ковалевский ${ }^{1,2 *}$, С.С. Оплачко ${ }^{3}$ К.С. Зубко ${ }^{3}$ Е.М. Лучникова ${ }^{3}$, А.Р. Ефимова ${ }^{4,5}$ В.Б. Ильяшенко ${ }^{2}$, А.В. Коршунов, Е.Д. Вдовина ${ }^{3}$, М.А. Носков ${ }^{3}$, Б.Г. Андреев ${ }^{6}$}

\footnotetext{
${ }^{l}$ Биологическая станиия «Ажендарово» Кемеровского государственного университета, ул. Красная, д. 6, Кемерово, 650000, Россия,

${ }^{2}$ Кафедра ландшафтной архитектуры Кузбасской государственной сельскохозяйственной академии, ул. Марковиева, д. 5, Кемерово, 650056, Россия.

${ }^{3}$ Кафедра экологии и природопользования Кемеровского государственного университета, ул. Красная, д. 6, Кемерово, 650056, Россия.

${ }^{4}$ Центр гигиены и эпидемиологи в Кемеровской области пр. Шахтёров, д. 20, Кемерово, 650002, Россия.

${ }^{5}$ Кафедра эпидемиологии Кемеровского государственного медииинского университета, ул. Ворочилова, д. 22A, Кемерово, 650056, Россия.

${ }^{6}$ Кафедра ботаники Томского государственного университета, Томск, ул. Ленина, д. 36, 634050, Россия.

*E-mail: passer125@yandex.ru
}

РЕЗЮМЕ. В ходе комплексных эколого-фаунистических полевых исследований в Кемеровской области в 2019 г. был уточнён характер распространения клеща Haemaphysalis concinna C.L. Koch, 1844. В окрестностях деревни Шестаково было собрано 488 особей данного вида, это самое северное местообитание вида из достоверно известных, расположенное в более чем в 170 км от ранее известной северной границы распространения. Ещё более северные находки этого вида являются единичными и вероятно связаны с заносом отдельных особей птицами. Обнаружение нового местообитания потребовало ревизии всей информации о распространении и прокормителях вида в Кузнецко-Салаирской горной области. В статье показано распространение Н. concinna в пределах региона. Так как в окрестностях деревни Шестаково подавляющее большинство личинок и нимф было обнаружено на варакушках Luscinia svecica (Linnaeus, 1758), в работе рассматривается возможный механизм возникновения подобных популяций $H$. concinna и роль птиц в распространении клеща.

Как цитировать эту статью: Kovalevskiy A.V., Oplachko S.S., Zubko K.S., Luchnikova E.M., Efimova A.R., Ilyashenko V.B., Korshunov A.V., Vdovina E.D., Andreyev B.G., Noskov M.A. 2020. Distribution and ecology of Haemaphysalis concinna (Parasitiformes, Ixodidae) in the Kuznetsk-Salair mountain area (Kemerovo region and adjacent regions, Russia) // Invert. Zool. Vol.17. No.2. P.133-144. doi: 10.15298/invertzool.17.2.03

КЛЮЧЕВЫЕ СЛОВА: Иксодовые клещи, популяция, распространение, птицы, миграция, Западная Сибирь, Алтай. 


\section{Introduction}

Ixodid ticks as carriers of many different zoonotic infections have long been an object of comprehensive study, both from a medical point of view and from a biological one. Despite careful attention to the issues of ixodid ticks arealogy and biology, there are currently species whose recent areas are poorly understood.

Haemaphysalis concinna C. L. Koch, 1844 also belongs to such species. Unfortunately, even that little information available is often scattered among disparate publications, often written in national languages, published in local collections and a long time ago. All this makes it difficult to access not only for the global scientific community (Rubel et al., 2018) but also for domestic authors (Filippova, 1997). So, in a generalizing monograph on the distribution of ixodid ticks in Western Siberia (Yakimenko et al., 2013), the Kemerovo region looks like terra incognita surrounded by more fully explored northern (Tomsk region) and southern (Altai Territory and the Altai Republic) territories on the tick distribution map placed in the book.

The work aimed to establish $H$. concinna distribution boundaries in the Kuznetsk-Salair mountain region based on modern literary source information, taking into account new data obtained by the authors, as well as assessing the possibility of tick transmission by birds at different periods of migratory mobility.

The Kemerovo region is mainly located in the Kuznetsk-Salair mountain region, which belongs to the Altai-Sayan highland. In the north and west, the region borders on the West Siberian highland. In the Kuznetsk-Salair mountain region, there are two types of relief. The mountainous territories include the ranges: Kuznetsk Alatau, Salair Ridge, Mountain Shoria (Gornaya Shoriya), and Biya Range; the plain land include Tom-Kolyvan Plain and Kuznetsk Depression. From the north, through the transitional forest-steppe region, the West Siberian Plain adjoins that region (Chernov et al., 1988).

The phytocenotic appearance of the region is partly represented by relict sites preserved from the preglacial period. The flat territories of the Kuznetsk depression are represented by the steppe and forest-steppe. Mountain and submountain areas of the region are characterized by a developed formation of black taiga and the presence of relict forests. In the south of the region, the Siberian linden Tilia sibirica Bayer, 1862 grows, which is considered as the remnant of broad-leaved forests of the Pliocene epoch (Kuminova, 1949; Kovrigina et al., 2015; Amelin, Blyakharchuk, 2016).

Such a combination of forests can create favorable conditions for $H$. concinna, whose range, according to some researchers, in the Asian part of Russia coincides with relict forests (Danchinova et al., 2007). In the region under consideration, the distribution area of $H$. concinna is mosaic in nature and is associated with drying hummocks along forest glades lowlands and marsh outskirts. This tick avoids dense forest plantations and dry lands. This tick avoids dense forest plantations and dry lands. In collections, even in the southern regions of the Kuznetsk depression, its share usually ranges from $1-6 \%$ of the total number of collected Ixodidae family ticks.

Biotopically ticks of $H$. concinna are most confined to moistened habitats. Humidity in habitats is $91-95 \%$, they are most active at +23 $\ldots+40^{\circ} \mathrm{C}$. Tick activation occurs early, even in the snow, when the daytime temperature rises above zero (Kalyagin, 1978; Kalyagin et al., 2005). The greatest abundance of hungry ticks lasts from about the 2nd decade of May to the 3rd decade of June (Belyantseva, Akulova, 1974; Yakimenko et al., 2013). Most often found on animals together with the taiga tick Ixodes persulcatus (Schulze, 1930) (Kalyagin et al., 2008).

\section{Material and methods}

The present work is based on an analysis of available literature and the results of our own research conducted in 2017-2019.

Tick counts in the area were carried out according to the common technique by a standard $60 \times 120 \mathrm{~cm}$ flag made of waffle cloth within the forest and forest-steppe zones of the 
Kemerovo region. The length of the recording route was measured using GPS/Glonass navigation (Yakimenko et al., 2013). For 2017-2019 in the general account, $417 \mathrm{~km}$ were passed with a flag at 17 points located in different parts of the region, $326 \mathrm{~km}$ of which were three routes, on which tick counts were carried out every 10 days in 2018-2019.

Ticks were also collected during inspections of birds, while studying migration processes. Bird infestation with ticks was evaluated in the summer of 2019 at the Azhendarovo biological station $\left(54^{\circ} 45^{\prime} \mathrm{N}, 87^{\circ} 01^{\prime} \mathrm{E}\right)$ and near the Shestakovo Village $\left(55^{\circ} 53^{\prime} \mathrm{N}, 87^{\circ} 57^{\prime} \mathrm{E}\right)$. Catching birds was carried out with ornithological mist nets, established in places where birds are crowded. Near the Shestakovo Village, seven nets were used installed in a swampy meadow; at the biostation -20 nets installed in coastal willow thickets and in ruderal meadows. The nets were checked every one to two hours from dawn to dusk. A total of 3,733 birds of 76 species were examined at the biostation from June 24 to August 22, 2019; From June 9 to July 4, 2019, 300 birds of 31 species were examined in the vicinity of Shestakovo. 109 ticks were collected from birds at the biological station; 488 specimens were collected near the Shestakovo. The bird examination and collection of ectoparasites was carried out according to generally accepted methods (Dubinina, 1971; Yakimenko et al., 2013).

The names of tick hosts are given according to the reports "Mammals of Russia" (Pavlinov, 2012) and IOC World Bird List (Gill, Donsker, 2019).

The terminology was used to characterize the birds' life cycle, according to which the following phases of life are distinguished in the annual cycle of Passeriformes Linnaeus, 1758: growth and development in the nest, juvenile (summer) migration, post-juvenile moulting, postnuptial (autumn) migration, wintering, premoulting, prenuptial (spring) migration, prenuptial activity, sexual activity (nest period), postnuptial (summer) migration, postnuptial molting, etc. Some species does not have all the life stages expressed. The use of the well-estab- lished terms "spring" and "autumn" migration, according to some ornithologists, does not correspond to modern concepts of bird migration, for example, autumn migration to wintering sites in a number of species occurs in the summer (Noskov, Rymkevich, 2008).

\section{Results}

N.N. Lebedeva and E.I. Korenberg (1981) distinguish 11 groups of $H$. concinna populations on the territory of the countries of the former USSR. Ticks inhabiting the territory of the Kuznetsk-Salair mountain region belong to the Altai group. H. concinna, found in the Minusinsk Depression (Fig. 1), belong to the Sayan group of populations. These two groups are divided among themselves with the mountains of Kuznetsk Alatau and Mountain Shoria.

In the Kuznetsk-Salair mountain region, among all ticks with a "pasture questing" type of parasitism, $H$. concinna can be considered as one of the least common species. A study by A.R. Efimova et al. (2017), based on archival data from entomological reports of the sanitary and epidemiological station of the Kemerovo region for 1970-1973 and its own materials for 2015 , shows that due to the mosaic distribution, the total proportion of tick species from the genera Dermacentor and Haemaphysalis does not exceed $1 \%$ of the total collection of ticks of the Ixodidae family from the Kemerovo region territory. According to the results of earlier studies conducted in 1952-1967, these genera accounted for about $13.5 \%$ of the total collection of ticks, of which $1.1 \%$ were diagnosed as H. concinna (Chigirik, Pleshivtseva-Eroshkina, 1969). Nevertheless, since in those years, the employees of the sanitary-epidemiological station could purposefully collect this type of tick for a more detailed study; it is not safe to say that in previous years the abundance of $H$. concinna was higher than now.

Available information allows us to outline the approximate distribution boundaries of $H$. concinna in the Kuznetsk-Salair mountain region (Fig. 1). Within the Kemerovo region, the greatest abundance of $H$. concinna was noted in 


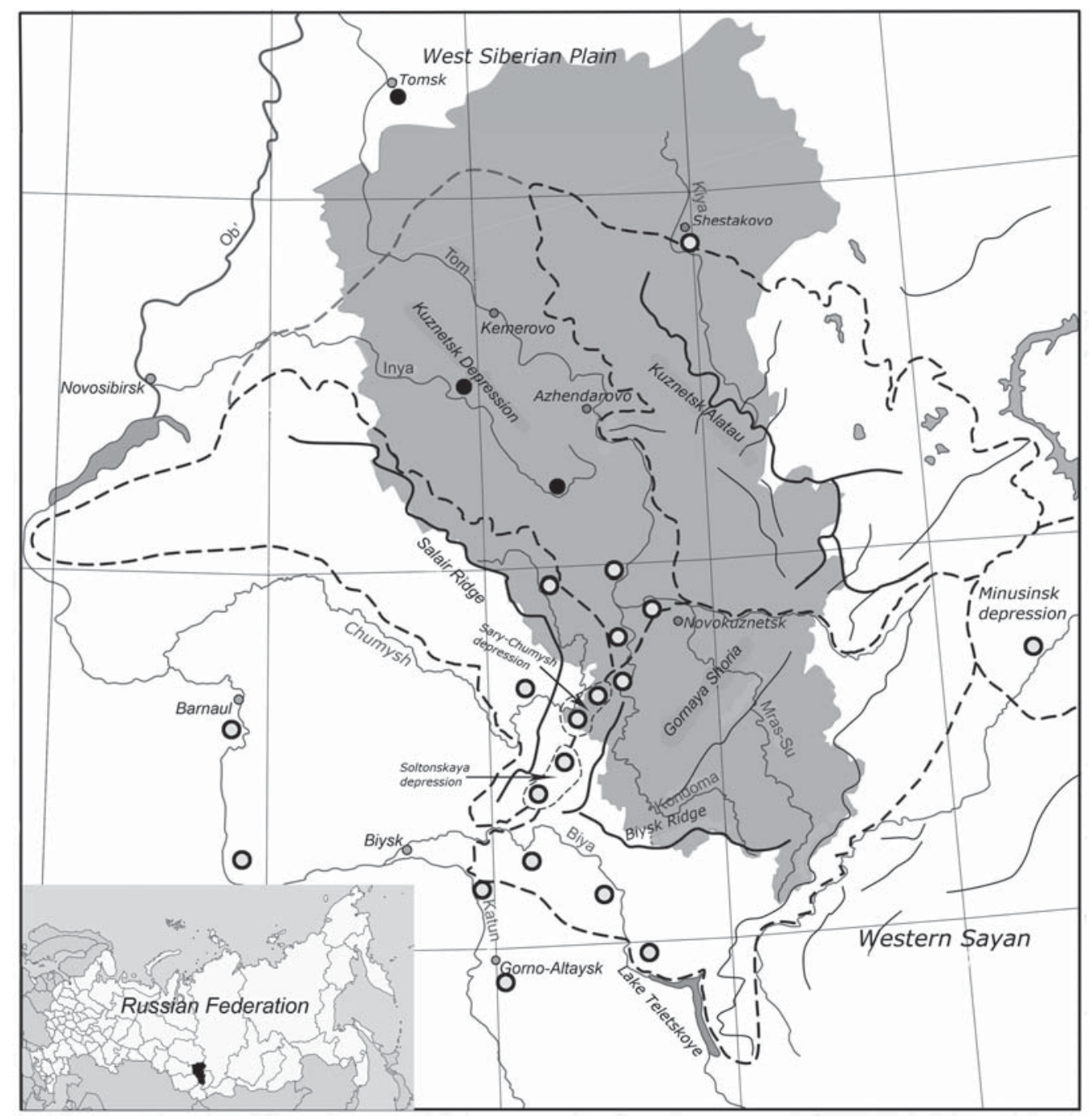

Fig. 1. Locations of Haemaphysalis concinna in the Kuznetsk-Salair mountain region. The territory of the Kemerovo region is highlighted in gray. The dotted line is the Kuznetsk-Salair mountain region and its provinces. Hollow circles are the habitats of H. concinna. Black circles are single detections of H. concinna specimens considered to be brought.

Рис. 1. Места обнаружения Haemaphysalis concinna в Кузнецко-Салаирской горной области. Серым цветом выделена территория Кемеровской области. Пунктир - Кузнецко-Салаирская горная область и её провинции. Полые круги - места постоянного обитания $H$. concinna Чёрные круги единичные обнаружения, отдельных особей $H$. concinna, рассматриваемые как заносные.

the southern part of the Kuznetsk Depression and in the Sary-Chumysh Depression. For the Kemerovo region, the southern border passes along the foothills of the Mountain Shoria (near the settlements: the village of Shartonka, the village of Kandalep, the village of the Ben- zherep-1, the village of the Benzherep-2, the village of Sary-Chumysh), and then through the intermountain Sary-Chumysh Depression and the Solton Depression goes south to Altai. It is in this area where the highest amount of $H$. concinna is observed for the Kemerovo region, 
where their rate reaches about $9 \%$ of all the collected ticks of the Ixodidae family. A separate population of $H$. concinna without the presence of other ixodid tick species was found in the vicinity of Kuzedeevo $\left(53^{\circ} 20^{\prime} \mathrm{N} 87^{\circ} 11^{\prime} \mathrm{E}\right)$ on the left bank of the Tesh River (Chigirik, Pleshivtseva-Eroshkina, 1969; Kovalevskiy et al., 2018a, b, 2019). According to the surveys we carried out on May 19, 2019 in the vicinity of the village of Kuzedeevo, the number of $H$. concinna was 0.9 specimens per flag-km. According to the literature in the Kuznetsk Depression, the abundance of $H$. concinna reaches 48 specimens per flag-km (Bogdanov, 2005). In the central part of Gornaya Shoria, only a few finds were noted near the village of Ust-Kabyrza in the valley of the Mrassu River (Kalyagin et al., 2005). In Altai (within the KuznetskSalair mountain region), these ticks are distributed in the Biya River Valley; in the south, the $H$. concinna range extends at least to the vicinity of Lake Teletskoye $\left(51^{\circ} 47^{\prime} \mathrm{N} 87^{\circ} 15^{\prime} \mathrm{E}\right)$. Findings are also known in the valley of the Katun River and its tributary of the Sema River (Koklyagina, 1963; Yakimenko et al., 2013; Butakov, 2016). According to the Altai Anti-Plague Station, the average abundance in the southern part of the Salair Ridge and in the marshy valleys of small rivers covered with dense shrubs and narrow strips of forest, the abundance of ticks is $38-75$ ticks $/ \mathrm{km}$, up to a maximum of 171 ticks/km (Bogdanov, 2005).

It is rather difficult to determine the northern distribution boundary of the species in the Kuznetsk-Salair mountain region due to the ability of $H$. concinna to form point populations that are difficult to differentiate from random bringing. Such isolated populations are known from the floodplains of the Kondoma, and Kinerka Rivers (Chigirik, Pleshivtseva-Eroshkina, 1969) and Chernovoy Naryk River (Belyantseva, Okulova, 1974). Until 2008, the northernmost (probably alien) find of $H$. concinna was considered a collection from the vicinity of Lebedi Village $\left(55^{\circ} 02^{\prime} \mathrm{N}, 85^{\circ} 35^{\prime} \mathrm{E}\right)$ of the Kemerovo Region (Chigirik, Pleshivtseva-Eroshkina, 1969). However, in 2008 V.N. Romanenko (2009), during monitoring studies, discovered single individu- als of ticks of this species on mammals in Tomsk $\left(56^{\circ} 29^{\prime} \mathrm{N}, 84^{\circ} 59^{\prime} \mathrm{E}\right)$. Subsequently, in Tomsk, during repeated work, no $H$. concinna specimens were found (Romanenko, 2011). Apparently, in this case we are dealing with a random bringing of ticks by migrating warm-blooded animals. In the course of our research, in the vicinity of Shestakovo Village $\left(55^{\circ} 53^{\prime} \mathrm{N}, 87^{\circ} 58^{\prime}\right.$ E) in the Shestakovo bogs in 2019, a new population of $H$. concinna was discovered, which is currently the northernmost known one (Fig. 1). During birds ringing in a swampy sedge meadow, 488 specimens of $H$. concinna were collected. On May 20, 2020, at the same place, 85 ticks of this species were collected on the flag; the abundance of the tick was 9.7 specimens per $\mathrm{km}$. The new point is located about $180 \mathrm{~km}$ northeast of Lebedi Village, and $170 \mathrm{~km}$ north of the mouth of the Chernovoy Naryk River. Judging by the abundance of ticks, it is the habitat of a stable isolated population unknown before.

Thus, within the Kuznetsk-Salair mountain region, the range of $H$. concinna is represented by two conditional groups. The first group is distributed in the southern part of the Kuznetsk depression, which is bounded by mountains from the west, south, and east, and extends to the north to approx. 54 parallel. This population group is associated through the Sary-Chumyshm and Salton Depressions (separating Mountain Shoria and Salair Ridge) with the more western and southern population groups in Altai, where the distribution zone passes through the low-mountain forests of the Biya river valley and its tributaries at least to the vicinity of Lake Teletskoye, as well as along the foothills and mountain steppes of Altai in the Katun River valley, already beyond the borders of the region in question.

The range of hosts for $H$. concinna within the Kuznetsk-Salair mountain region is very wide (Popov, 1962; Kalyagin et al., 2005, 2008). Parasitism of this species' females was observed in domestic animals (cows, horses, sheeps). In this case, parasitism usually occurred simultaneously with the taiga tick I. persulcatus on the same animal. In some cases, 
parasitism in domestic animals is widespread.

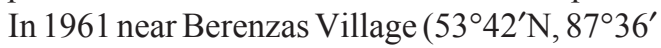
$\mathrm{E})$ in the second half of May, on average about 20 specimens of $H$. concinna were occurred on one cow.

The larvae and nymphs of $H$. concinna feed on small mammals: Apodemus agrarius (Pallas, 1771), A.peninsulae (Thomas, 1907), Micromys minutus (Pallas, 1771), Myodes glareolus (Schreber, 1780), Crocidura sibirica (Dukelsky, 1930), Cricetus cricetus (Linnaeus, 1758) (Kalyagin et al., 2005; 2008).

In general, this tick species shows rather high confinement to birds, and, according to I.I. Bogdanov (2005), the northern part of $H$. concinna range was formed due to pre-nuptial (spring) bird migrations. Confirmation of the thesis about birds moving ticks to the north during pre-nuptial migrations over significant distances is the finding of $H$. concinna beyond the Arctic Circle near the Taimyr Peninsula (Bogdanov, 2000; Rubel et al., 2018), more than 1.5 thousand $\mathrm{km}$ north of the main range. Only during the migration of birds to nesting sites, ticks can be introduced over such long distances.

When $H$. concinna enters the optimal biotopes, it can form more or less stable populations, which leads to the mosaic distribution of the ticks. During moving to the north, there was some biotopic inversion, because this species found more suitable places not in forests, where there is not enough heat at sufficient humidity, but in more heated humid areas of open biotopes. Also, when moving to the north the tick developed cycle break down into 2-3 years without hereditary fixation. Under optimal conditions, the development cycle goes on without a break for 58-60 days (Bogdanov, 2005).

In Western Siberia, 43 species of birds are known as hosts for $H$. concinna (Bogdanov, 2005; Yakimenko et al. 2013). To date, we have found parasitism for six species of Passeriformes Linnaeus, 1758 in the vicinity of Shestakovo Village, e.g. Anthus trivialis (Linnaeus, 1758), Emberiza schoeniclus (Linnaeus, 1758), Helopsaltes certhiola (Pallas, 1811), Calliope calliope (Pallas, 1776), bluethroat Luscinia svecica (Linnaeus, 1758), Motacilla citreola (Pallas, 1776).

One of the main hosts of $H$. concinna among birds is bluethroat, from which $95 \%$ of ticks at the stage of larva and nymph were found in the vicinity of Shestakovo Village (Table 1). Activation of $H$. concinna imago is observed in the second decade of April and the second decade of July with a maximum number in the second decade of May and the third decade of June. Larvae and nymphs are found in nature from the third decade of May to the end of August, with a maximum number at the end of June (Belyantseva, Okulova, 1974; Bogdanov, 2005; Yakimenko et al., 2013).

It is noteworthy that the periods of maximum activity of $H$. concinna larvae and nymphs coincide with the beginning of the nest leave of bluethroat one-year birds (Fig. 2). For the period preceding the leave, only two ticks were found on 13 birds, while 460 larvae and nymphs of $H$. concinna were found on 33 bluethroats from June 28 to July 4, 2019. However, despite the high degree of bluethroat infestation with ticks in late June and early July, its contribution to the resettlement of the studied tick species during this period is relatively small.

Comparing the periods of molts and migrations of bluethroat and the phases of H. concinna life cycle, the following can be seen. The greatest abundance of $H$. concinna larvae and nymphs coincides with the stages of juvenile and postnuptial migration of bluethroat. These stages are short and quickly turn into the molting stage when the birds become less mobile. Considering that the duration of larvae and nymphs feeding is 3-5 days (Popov, 1962; Bogdanov, 2005), the distribution of ticks with bluethroats will occur only in adjacent habitats. Literature data indicate that at a distance of 200-300 km from nesting sites, bluethroats begin to be recorded from August to September, that is, during the postmoulting migration directed to wintering sites (Lindström, Lind, 2001). In a biologically and taxonomically close species, the song thrush Turdus philomelos Brehm, 1831, the range of post-nest migration rarely reaches $20 \mathrm{~km}$ and very rarely exceeds this value (Milwright, 2006). 
Table 1. Birds infestation by ticks Haemaphysalis concinna and Ixodes persulcatus (vicinity of Shestakovo Village). Таблица 1. Заражённость птиц клещами Haemaphysalis concinna и Ixodes persulcatus (окр. д. Шестаково).

\begin{tabular}{|c|c|c|c|c|c|c|c|c|}
\hline \multirow[b]{2}{*}{ Species } & \multirow{2}{*}{ 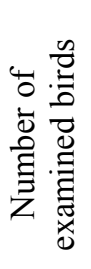 } & \multirow{2}{*}{ 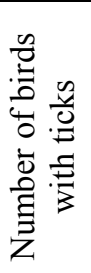 } & \multicolumn{3}{|c|}{$\begin{array}{l}\text { Haemaphysalis } \\
\text { concinna }\end{array}$} & \multicolumn{3}{|c|}{ Ixodes persulcatus } \\
\hline & & & 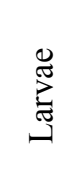 & 竞 & 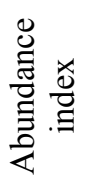 & $\underset{\Xi}{\mathbb{J}}$ & $\frac{n}{\text { a }}$ & 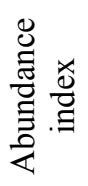 \\
\hline $\begin{array}{l}\text { Luscinia svecica } \\
\text { (Linnaeus, 1758) }\end{array}$ & 70 & 35 & 314 & 148 & 6.6 & 4 & 5 & 0.1 \\
\hline $\begin{array}{l}\text { Emberiza schoeniclus } \\
\text { (Linnaeus, 1758) }\end{array}$ & 5 & 1 & 9 & 0 & 1.8 & 0 & 0 & 0 \\
\hline $\begin{array}{l}\text { Luscinia calliope } \\
\text { (Pallas, 1776) }\end{array}$ & 9 & 4 & 6 & 3 & 1.0 & 0 & 0 & 0 \\
\hline $\begin{array}{l}\text { Helopsaltes certhiola } \\
\text { (Pallas, 1811) }\end{array}$ & 8 & 5 & 4 & 2 & 0.8 & 0 & 0 & 0 \\
\hline $\begin{array}{l}\text { Anthus trivialis } \\
\text { (Linnaeus, 1758) }\end{array}$ & 8 & 1 & 1 & 0 & 0.1 & 0 & 0 & 0 \\
\hline $\begin{array}{l}\text { Motacilla citreola } \\
\text { (Pallas, 1776) }\end{array}$ & 10 & 1 & 0 & 1 & 0.1 & 0 & 0 & 0 \\
\hline Other species* & 190 & 0 & 0 & 0 & 0 & 0 & 0 & 0 \\
\hline
\end{tabular}

* Columba livia (Gmelin, 1789) - 1 specimen; Jynx torquilla (Linnaeus, 1758) - 2; Sturnus vulgaris Linnaeus, 1758 - 2; Acrocephalus dumetorum Blyth, $1849-25$; Iduna caligata (Lichtenstein, 1823) - 8; Sylvia communis (Latham, 1787) - 6; Sylvia curruca (Linnaeus, 1758) - 3; Phylloscopus trochilus (Linnaeus, 1758) — 5; Phylloscopus collybita (Vieillot, 1817) - 15; Phylloscopus fuscatus (Blyth, 1842) - 5; Phylloscopus schwarzi (Radde, 1863) - 1; Ficedula albicilla (Pallas, 1811) - 1; Saxicola maurus (Pallas, 1773) - 1; Larvivora cyane (Pallas, 1776) - 2; Turdus pilaris (Linnaeus, 1758) - 4; Aegithalos caudatus (Linnaeus, 1758) - 3; Poecile montanus (Conrad von Baldenstein, 1827) - 8; Periparus ater (Linnaeus, 1758) - 1; Cyanistes cyanus Pallas, 1770 - 1; Parus major Linnaeus, 1758 1; Passer domesticus (Linnaeus, 1758) - 1 Passer montanus (Linnaeus, 1758) - 40; Carduelis carduelis Linnaeus, 1758 - 3; Chloris chloris (Linnaeus, 1758) - 5; Carpodacus erythrinus (Pallas, 1770) - 23; Carpodacus sibiricus (Pallas, 1773) - 18; Emberiza citrinella (Linnaeus, 1758) - 5.

Thus, the most likely way of moving $H$. concinna to the north and the formation of isolated groups is the transfer of ticks along with birds during prenuptial migrations. The distribution of $H$. concinna during prenuptial and juvenile migrations will contribute to the spread of ticks to nearby distances of no more than 10 $20 \mathrm{~km}$.

Taking into account the nature of regional migrations (Savchenko, 2009), it is most likely that the identified habitat in the vicinity of Shestakovo Village may be of eastern origin, associated with the Minusinsk Depression and the forest-steppe part of the West Sayan mountain taiga region (Khazova, 2007).
Ticks transfer most likely occurred during prenuptial migration of East Palaearctic species of birds flying from the east and bypassing the mountainous regions of the Altai-Sayan Highland (Fig. 3). The transfer of H. concinna from the southern regions of the Kuznetsk Depression is unlikely since the main "transit" migration routes of birds go around the KuznetskSalair mountain region. No pronounced movements of birds from the south of the Kuznetsk depression to the north of the depression and vice versa are not observed (Kovalevsky, 2015).

North transfer of $H$. concinna occurs regularly by birds. However, a shortage of suitable biotopes and an insufficient number of ticks to 


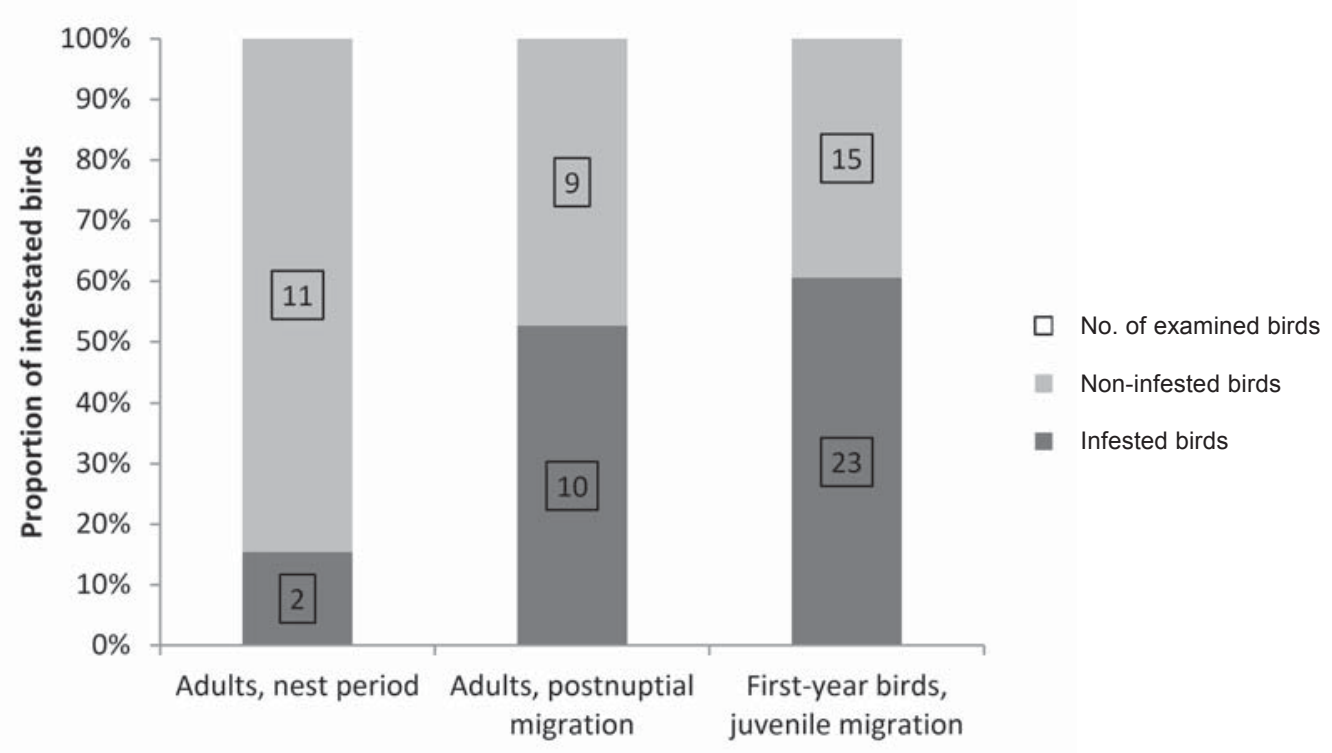

Fig. 2. The proportion of bluethroats Luscinia svecica that were infestated by Haemaphysalis concinna, according to the results of captures in the vicinity of Shestakovo Village.

Рис. 2. Доля варакушек, заклещевлённых Haemaphysalis concinna, по результатам отловов в окрестностях д. Шестаково.

form a stable population complicate the formation of new habitats. Ticks that have fallen off and subsequently metamorphosed into adults will not be able to start reproduction, because in the new biotope the probability of meeting a partner for replication is extremely low. S.P. Chunikhin and L.K. Berezina (1969) on the example of the relationship Ix. persulcatus and Ix. pavlovskyi with thrushes Turdus (Linnaeus, 1758), note the possibility of the successful distribution of ixodid ticks by birds during migrations in areas subject to large-scale acaricidal treatment. However, the number of ticks carried by thrushes and other birds is usually not enough to form stable ixodid tick populations (Chunikhin, 1969).

\section{Discussion}

In the Kuznetsk-Salair mountain region, $H$. concinna is distributed in the southern part of the Kuznetsk Depression, where through the Sary-Chumysh and Solton Depressions this group of tick populations communicates with more southern populations living in the foothills and mountain steppes of Altai, as well as in the valleys of the Biya and Katun Rivers. In the northern periphery of the range, ticks are relatively regularly found up to approximately 54 parallel.

Further north, isolated populations may form, an example of which is the "Shestakovo" habitat $\left(55^{\circ} 53^{\prime} \mathrm{N}, 87^{\circ} 58^{\prime} \mathrm{E}\right)$ discovered by us. Currently, this is the northernmost point of the species range. Possibly, there are intermediate populations that do not form a continuous range in river valleys from the Shestokovo marshes to the Minusinsk Depression.

The distribution of $H$. concinna to the north is associated with birds migrating to nesting sites. Given the circumstances of local bird migrations, the most likely movement of $H$. concinna to the vicinity of Shestakovo Village came from southeastern populations of the Sayan group ticks from the foothills of the Western Sayan mountains. The transfer of ticks from the southern part of the Kuznetsk Depression (that is, from populations of the Altai group) is unlikely.

The distribution of larvae and nymphs of $H$. concinna during the post-nesting leave of chicks 


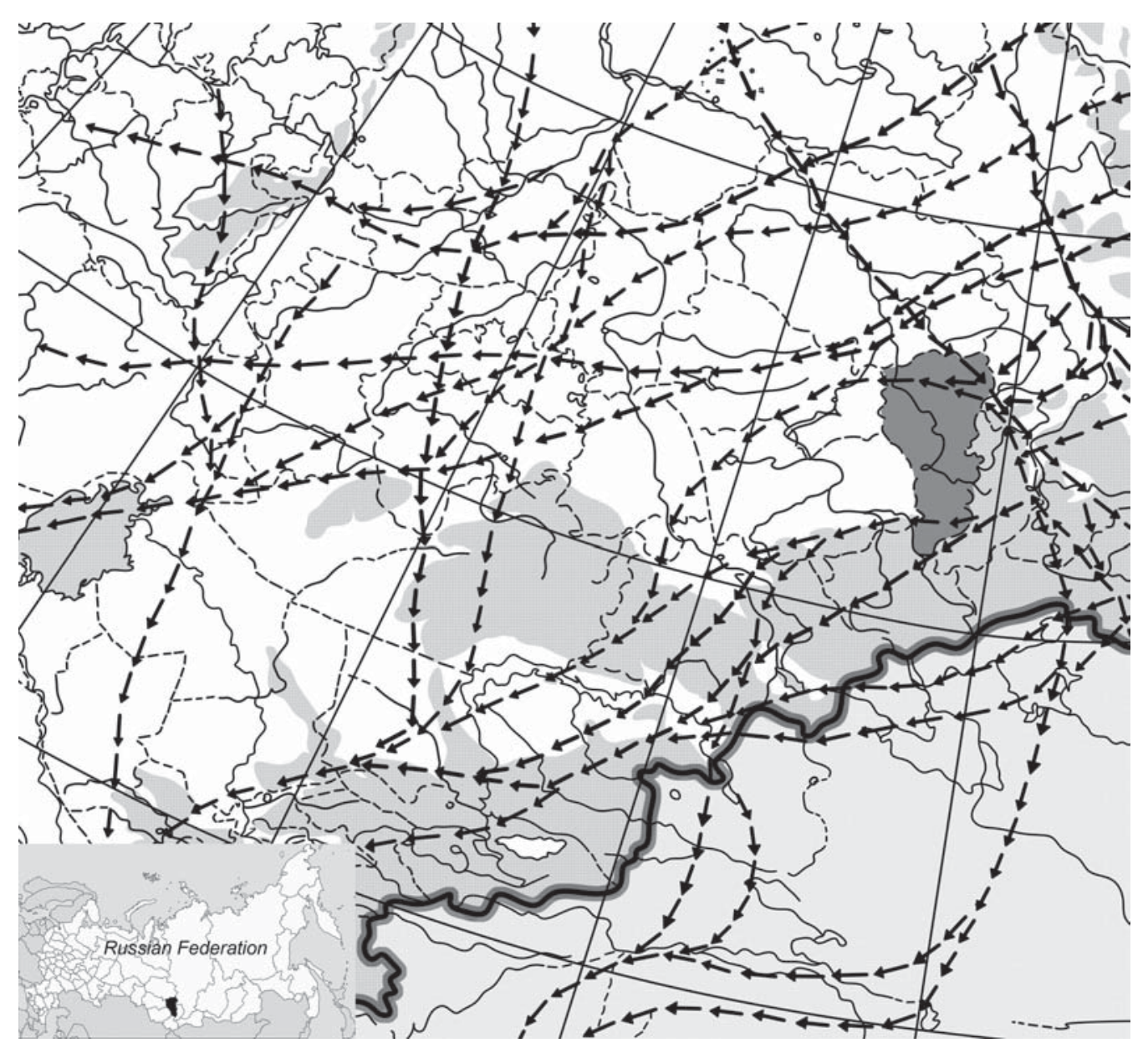

Fig. 3. Regional birds' migration routes (according to Savchenko [2009]).

Рис. 3. Региональные миграционные пути птиц (по Савченко, 2009).

will not occur over long distances and will be limited to a maximum of $10-20 \mathrm{~km}$.

Birds regularly bring $H$. concinna to the north during premarital migrations. However, the formation of new tick habitats on the northern periphery of the range is limited by a deficit of moist and well-warmed biotopes and an insufficient number of ticks carried by birds necessary for the formation of stable populations.

To study the ability of migratory birds to spread ixodid ticks, it is necessary to detail migration paths on a "local" scale. Despite the fact that this problem was identified more than 40 years ago (Ilyichev, 1979), the local migra- tion routes of many bird species are still a poorly studied side of modern ornithology.

Acknowledgements. This work is financially supported by the Russian Foundation for Basic Research (grant No. 20-44-420008\20).

We are deeply grateful to Anna A. Vasilieva for translating this paper into English.

\section{References}

Amelin I.I., Blyakharchuk T.A. 2016. [Distribution of Siberian linden (Tilia sibirica Bayer) in the Kemerovo oblast] // Vestnik Tomskogo Universiteta. Biologiya. Is.2. No.34. P.30-52 [in Russian, with English summary]. 
Belyantseva G.I., Okulova N.M. 1974. [Seasonal changes in the activity of ixodid ticks in the natural focus of tick-borne encephalitis in the south of the Kemerovo region]// Meditsinskaya parazitologiya i parazitarnyye bolezni. No.6. P.710-715 [in Russian].

Bogdanov I.I. 2000. [Ixodid ticks (Acari, Parasitiformes, Ixodidae) of Western Siberia. Message II. The structure of habitats] // Estestvennyye nauki i ekologiya: Ezhegodnik. Issue 5. Omsk: Publishing House of OmGPU. P.200-204 [in Russian].

Bogdanov I.I. 2005. [Ixodid ticks (Ixodidae, Parasitiformes) of Western Siberia. Message VI. Haemaphysalis concinna Koch in Western Siberia] // Estestvennyye nauki i ekologiya: Ezhegodnik. Issue 9. Omsk: Publishing House of OmGPU. P.173-175 [in Russian].

Butakov E.I. 2016. [Efficiency of insectic-aricidal preparations based on natural biologically active substances against the most common ectoparasites of farm animals]. PhD dissertation (biology). Moscow. 151 p. [In Russian].

Chernov G.A., Vdovin V.V., Okishev P.A., Petkevich M.V., Mistryukov A.A., Zatkova L.K., Milyaeva L.S. 1988. [Relief of the Altai-Sayan mountain region]. Novosibirsk: Nauka Publ. 206 p. [In Russian].

Chigirik E.D., Pleshivtseva-Eroshkina E.A. 1969. [Ixodid ticks of the Kemerovo region] // Meditsinskaya parazitologiya i parazitarnyye bolezni. No.4. P.423-426 [in Russian].

Chunikhin S.P. 1969. [Role of Birds in the Restoration of Forest Tick Population (Ixodes persulcatus)] // Perelyotnye ptitsy i ikh rol' $\mathrm{v}$ rasprostranenii arbovirusov. Novosibirsk: Nauka Publ., Siberian Branch. P.186192 [in Russian].

Chunikhin S.P., Berezina L.K. 1969. [On Feeding of Forest Tick imago (Ixodes persulcatus) in foci of Tick Encephalitis in the Salair Ridge and Kuznetsk Alatau] // Perelyotnye ptitsy i ikh rol'v rasprostranenii arbovirusov. Novosibirsk: Nauka Publ. P.193-196 [in Russian].

Danchinova G.A., Khasnatinov M.A., Shulunov S.S., Arbatskaya E.V., Badueva L.B., Suntsova O.V., Tchaporgina E.A., Bogomazova O.L., Timoshenko A.F. 2007. [Fauna and ecology of ixodid tick in Pribaikaly] // Acta Biomedica Scientifica. Vol.3. No.55. P.86-89 [in Russian].

Dubinina M.N. 1971. [Parasitological study of birds.] Moscow: Nauka. 139 p. [In Russian]

Efimova A.R., Rudakova S.A., Drozdova O.M., Rudakov N.V., Yakimenko V.V. 2017. [Carrier species of tickborne infections in Kemerovo region] // Fundamental'naya i klinicheskaya meditsina. Vol.2. No.2. P.6-13 [in Russian] DOI 10.23946/2500-0764-20172-2-6-13.

Filippova N.A. 1997. [Ixodid ticks of subfamily Amblyomminae] // Fauna Rossii i sopredel'nykh stran. Paukoobraznye. Vol.4. Issue 5. St. Petersburg: Nauka Publ. 436 p. [In Russian]

Gill F., Donsker D. (eds.). 2019. IOC World Bird List (v 9.2). doi: 10.14344/IOC.ML.9.2. URL: https:// www.worldbirdnames.org/ (date of access 20.11. 2019).

Ilyichev V.D. 1979. [Migrations of birds and their epidemiological significance] // Migratsii ptits i perenos vozbuditeley infektsiy. Moscow: Nauka Publ. P.205221 [in Russian].

Kalyagin Yu.S. 1978. [Micromorphological adaptations of ixodid ticks to a parasitic lifestyle]. Abstract to $\mathrm{PhD}$ Thesis. Alma-Ata. 20 p. [In Russian]

Kalyagin Yu.S., Baranov E.N., Bogdanov V.R., Zubko K.S. 2005. [Ixodid ticks in the ecosystems of Gornaya Shoria] // Trudy Tigirekskogo zapovednika. T.1. P.295-296 [in Russian].

Kalyagin Yu.S., Baranov E.N., Bogdanov V.R., Zubko K.S. 2008. [The main results of ecological and faunistic studies of ixodid ticks of the Kemerovo Region at the Department of Zoology and Ecology of Kemerovo State University] // Entomologicheskiye issledovaniya v Zapadnoy Sibiri. Trudy Kemerovskogo otdeleniya Russkogo entomologicheskogo obshchestva. P.4350 [in Russian].

Khazova T.G. 2007. [Ecological and parasitological characterization of tick-borne encephalitis natural foci in Krasnoyarsk region] // Byulleten' Sibirskogo Otdeleniya RAMN. No.4 (126). P.94-99 [in Russian, with English summary].

Koklyagina A.A. 1963. [Fauna of ixodid ticks of the Altai] // Kleshchevoy entsefalit v Altayskom kraye. Barnaul. P.19-25 [in Russian].

Kovalevskiy A.V. 2015. [Migration of passerine birds of the Kuznetsk Depression in the summer-autumn period]. $\mathrm{PhD}$ dissertation (biology). Kemerovo. 211 p. [In Russian]

Kovalevskiy A.V., Zubko K.S., Efimova A.R., Luchnikova E.M., Drozdova O.M. 2018a. Distribution and some biological features of ixodid ticks (Parasitiformes, Ixodidae) in Kuznetsk-Salair mountain area (Kemerovo province, Russia) // Entomological Review. T.98. No.9. P.1379-1388.

Kovalevskiy A.V., Zubko K.S., Efimova A.R., Luchnikova E.M., Drozdova O.M. 2018b. [Distribution and some biological features of ixodid ticks (Parasitiformes, Ixodidae) in Kuznetsk-Salair mountain area (Kemerovo province, Russia)] // Parasitologiya. Vol.52. No.5. P.403-416 [in Russian, with English summary].

Kovalevskiy A.V., Zubko K.S., Efimova A.R., Luchnikova E.M., Drozdova O.M. 2019. Erratum to: Distribution and some biological features of ixodid ticks (Parasitiformes, Ixodidae) in Kuznetsk-Salair mountain area (Kemerovo province, Russia) // Entomological Review. Vol.99. No.1. P.135.

Kovrigina L.N., Romanova N.G., Tarasova I.V., Filippova A.V. 2015. [The condition of coenotic populations of Tilia sibirica Bayer, 1862 in Kemerovo Region] // Vestnik Kemerovskogo gosud. universiteta. Vol.4-3. No.63. P.31-34 [in Russian].

Kuminova A.V. 1949. [Vegetation of the Kemerovo region]. Novosibirsk. 167 p. [In Russian]

Lebedeva N.N., Korenberg E.I. 1981. Distribution of 
Haemaphysalis concinna Koch in the Soviet Union and some general features of its ecology // Folia parasitologica (Praha). Vol.28. P.249-261.

Lindström A., Lind J. 2001. Fuel deposition and speed of early autumn migration of juvenile Bluethroats Luscinia s. svecica leaving their natal area in Swedish Lapland // Ornis svecica. Vol.11. P.253-264.

Milwright R.D.P. 2006. Post-breeding dispersal, breeding site fidelity and migration/wintering areas of migratory populations of Song Thrush Turdus philomelos in the Western Palearctic// Ringing \& Migration. Vol.23. No.1. Đ.21-32.

Noskov G.A., Rymkevich T.A. 2008. [The migration activity in the annual cycle of birds and its forms] // Zoologicheskiy zhurnal. Vol.87. No.4. P.446-457 [in Russian, with English summary].

Pavlinov I.Ya. 2012. The mammals of Russia: a taxonomic and geographic reference // I.Ya. Pavlinov, A.A. Lisovsky (eds.). Sbornik trudov Zoologicheskogo Muzeya MGU. Moscow: KMK Scientific Press. Vol.52. 604 p. Popov V.M. 1962. [Ixodid ticks of Western Siberia]. Tomsk. 260 p. [In Russian]
Romanenko V.N. 2009. [Monitoring of bio-diversity and density of ixodes ticks (Parasitiformes, Ixodidae) in urban environment] // Vestnik Tomskogo gosud. universiteta. No.324. P.376-379 [in Russian].

Romanenko V.N. 2011. [Long-term dynamics of density and diversity of ticks (Ixodidae) on the natural and disturbed territories] // Parasitologiya. Vol.45. No.5. P.384-391 [in Russian, with English summary].

Rubel F., Brugger K., Walter M., Vogelgesang J.R., Didyk Yu.M., Fu S., Kahl O. 2018. Geographical distribution, climate adaptation and vector competence of the Eurasian hard tick Haemaphysalis concinna // Ticks and Tick-borne Diseases Vol.9. P.1080-1089.

Savchenko A.P. 2009. [Migrations of terrestrial vertebrates of Central Siberia and environmental safety problems]. Abstract of PhD Thesis. Ulan-Ude. 49 p. [In Russian]

Yakimenko V.V., Malkova M.G., Shpynov S.N. 2013. [Ixodid ticks of Western Siberia: fauna, ecology, basic research methods]. Omsk: Omskiy nauchnyi vestnik Publ. Ltd. 240 p. [In Russian]

Responsible editor K.G. Mikhailov 